\title{
Analisis Wacana Kritis Monolog Dalam Talk Show Mata Najwa Edisi "Menanti Terawan"
}

\author{
Nur Lailiyah'1, Favorita Kurwidaria², Farida Indri W' ${ }^{3}$, Sumarlam ${ }^{4}$ \\ lailiya86@unpkediri.ac.id¹; favorita.kurwidaria282@gmail.com²; Faridaindri25@gmail.com³; \\ sumarlam@staff.uns.ac.id 4 \\ Universitas Nusantara PGRI Kediri¹, Universitas Sebelas Maret2,4, Institut Agama Islam Negeri \\ Surakarta ${ }^{3}$
}

\begin{abstract}
This study aims to analyze the elements of text, interpretation, and explanation using a critical discourse analysis approach. The textual strategy focuses on choosing the right vocabulary and the use of certain grammar. The method used is the watch-free-to-talk (SBLC) method with the note-taking technique. This type of qualitative descriptive research, while the data analysis technique is carried out by referring to the framework of Fairclough's discourse analysis dimensions, namely: text analysis, namely descriptions, interpretations, and explanations that will be used as techniques in data analysis. The results obtained are as follows: first, the types of sentences used include directive, interrogative and imperative which are also strategies for text producers to show their ideology, as well as indirect assessments of participants. Second, the vocabulary used has the purpose of emphasizing, and obscuring the real meaning. In addition to the vocabulary, the textual analysis also includes grammatical aspects by utilizing transitivity, positive-negative sentences, and modalities, as well as utilizing textual structures that are in accordance with the inverted pyramid using the news text construction pattern. So that in the socio-cultural dimension there are changes in situations, changes in institutions, and social changes.
\end{abstract}

Keywords: critical discourse analysis, monologue, mata najwa

\section{ABSTRAK}

Penelitian ini bertujuan untuk menganalisis unsur teks, interpretasi dan eksplanasi menggunakan pendekatan analisis wacana kritis. Strategi tekstual berfokus tentang pemilihan kosakata yang tepat dan penggunaan tata bahasa tertentu. Metode yang digunakan adalah, metode simak-bebas-libatcakap (SBLC) dengan teknik catat. Jenis penelitian kualitatif deskriptif, sedangkan teknik analisis data dilakukan dengan mengacu pada kerangka dimensi analisis wacana Fairclough yaitu: analisis teks yaitu deskripsi, interpretasi dan eksplanasi yang akan digunakan sebagai teknik dalam analisis data. Hasil penelitian diperoleh sebagai berikut: pertama, jenis kalimat yang digunakan meliputi direktif, interogatif dan imperatif yang juga merupakan strategi bagi pemroduksi teks dalam menunjukkan ideologinya, serta penilaian secara tidak langsung terhadap partisipan. Kedua, kosakata yang digunakan memiliki tujuan untuk menegaskan, dan mengaburkan maksud yang sebenarnya. Selain kosakata tersebut, analisis tekstual juga meliputi aspek ketatabahasaan dengan mendayagunakan ketransitivan, kalimat positif-negatif, dan modalitas, serta men-dayaguna-kan struktur tekstual yang sesuai dengan piramida terbalik dengan menggunakan pola konstruksi teks berita. Sehingga dalam dimensi sosial-kultural adanya perubahan situasi, perubahan instritusi dan perubahan sosial.

Kata Kunci: analisis wacana kritis, monolog, mata najwa

\section{PENDAHULUAN}

Bahasa pada haklkatnya terdiri atas kategori yaitu bentuk dan makna, hubungan antar bagian dari wacana yang dapat dibedakan menjadi dua jenis, yaitu: hubungan bentuk (kohesi), dan hubungan makna (koherensi). Wacana yang padu dapat dikatakan sebagai wacana, yang jika dilihat dari hubungan bentuknya bersifat kohesif dan apabila dilihat dari hubungan maknanya bersifat koheren (Sumarlam, 2005: 23). Kohesi menurut Halliday (Sumarlam, 2005: 23) dibedakan menjadi dua: kohesi leksikal dan kohesi gramatikal. 
Pemakaian bahasa didalam berkomunikasi, ada dua cara yang dapat dilakukan, seperti: lisan dan tulisan yang juga bisa disebut sebagai wacana (Cook, 1989: 7). Studi bahasa yang berfokus mengamati, bagaimana orang menggunakan bahasanya untuk berkomunikasi. Selanjutnya, bagaimana pembicara atau penutur menyusun pesan linguistik (bahasanya) kepada orang lain, dan bagaimana orang lain mengerjakan pesan linguistik tersebut untuk ditafsirkan disebut Analisis wacana..

Percakapan tergolong dalam wacana lisan, yang selalu memberikan makna yang memiliki tujuan dan maksud tertentu. Wacana lisan merupakan wacana yang cara penyampaiannya dengan bahasa lisan danatau melalui media lisan. Dalam bahasa lisan, dalam memahami wacana lisan maka pendengar atau lawan tutur harus menyimaknya dengan baik. Dalam konteks wacana lisan, terjadi komunikasi dua arah secara langsung antara pembicara (penutur) dengan pendengar (lawan tutur). Tidak terkecuali dalam sebuah tayangan program acara di televisi.

Talkshow Mata Najwa merupakan acara televisi yang berupa perbincangan seseorang dengan "tamu" yang membahas tentang suatu topik tertentu. Talkshow yang dipandu oleh Najwa Sihap, yakni Mata Najwa memiliki keunikan dan kekhasan yang tidak dimiliki oleh acara talkshow lainnya, hal tersebut terletak pada pembawa acara, yang memiliki ciri khas tersendiri (Putri, 2019), selain itu setiap topik yang diangkat selalu menarik yang disajikan secara mendalam. Sajian dari topik yang diangkat selalu faktual dan aktual, dalam acara tersebut narasumber yang dihadirkan memiliki kredibilitas yang tinggi dengan topik yang diangkat.

Kondisi pandemi Covid 19, yang terjadi saat ini, membuat acara tersebut berusaha mengangkat topik yang berkaitan dengan pandemi yang belum juga terkendali, dengan mengundang Meteri Kesehatan Terawan Agus Putranto diharapkan mampu mendedah kebijakan-kebijakannya terkait penanganan situasi pandemi Covid-19. Sayangnya, berkali-kali menteri kesehatan Terawan Agus Putranto diundang dalam acara tersebut tidak memenuhi undangan, sehingga acara tersebut dilakukan secara monolog tanpa kehadiran menteri kesehatan.

Ada banyak hal yang perlu diperhati-kan dalam acara talkshow tersebut, yakni aspek gramatikal dan aspek leksikal yang digunakan oleh Najwa Sihab dalam beretorika sebagai unsur penting dalam membangun persepsi khalayak. Penelitian ini mengkaji penggunaan kohesi gramatikal dan leksikal dalam talkshow di Trans7 "Mata Najwa" yang bertopik "Menanti Terawan".

Payuyasa (2017) telah melakukan penelitian, yang memfokuskan mengenai analisis wacana kritis pada program acara mata najwa dengan model Van dijk dalam wacana politik yaitu babak final pilkada Jakarta. Berbeda dari penelitian sebelumnya yang dilakukan oleh (Sosiowati, 2013; Saifudin, 2013; Wibowo, 2013; dan Mardikantoro, 2014) dalam penelitian ini wacana monolog dalam talk show dengan tema power challenge dengan topik "Menanti Terawan" akan dibedah berdasarkan pisau analisis wacana kritis model Norman-Fairclough.

Analisis teks dapat difokuskan pada wujud teks secara keseluruhan, yaitu dengan melihat buktibukti linguistik berupa aspek kosakata, semantis, tata kalimat. Selain itu, juga dapat menyertakan aspek kohesivitas dan koherensi, bagaimana antarunsur tersebut dihubungkan sehingga, akan membentuk pengertian. Semua aspek-aspek yang dianalisis tersebut, bertujuan untuk dapat menguraikan tiga hal penting, yaitu: ideasional, relasi dan identitas.

Analisis praktik wacana memfokuskan perhatiannya pada perwujudan teks, bagaimana cara teks tersebut diproduksi (oleh wartawan atau media) dan dikonsumsi (oleh khalayak atau masyarakat). Pada analisis praktik wacana, yang dilakukan dengan mencari hubungan-nya antara interpretasi-teks dan interpretasi-konteks. Interpretasi-teks dilakukan dalam empat tahapan: ujaran, makna ujaran, koherensi 
lokal dan keutuhan wacana. Sedangkan intepretasi-konteks dilakukan pada dua tataran yaitu konteks situasi dan intertekstualitas (Sumarlam, 2016: 3).

Sedangkan pada analisis sosiokultural, berkaitan dengan konteks sosial budaya yang ikut berpengaruh pada perwujudan teks. Pada pembahasan praktik sosiokultural, diwujudkan dalam tiga aspek, yakni: situasional, institusional dan sosial. Aspek situasional berkaitan dengan konteks situasi yang turut berpengaruh pada produksi teks. Aspek institusional melihat bagaimana institusi organisasi berpengaruh pada produksi teks baik secara internal maupun eksternal. Sedangkan aspek sosial berkaitan dengan konteks yang lebih luas, seperti: sistem ekonomi, politik, budaya dari masyarakat secara menyeluruh.

Dengan demikian, dapat dikatakan pada analisis wacana ini, ketiga aspek tersebut akan berkaitan dengan situasi atau kondisi saat teks monolog talkshow Mata Najwa dibuat, institusi yang turut menjadi pemicu munculnya teks tersebut, sampai pada situasi atau realita sosial yang terjadi di masyarakat.

\section{METODE PENELITIAN}

Dalam penelitian ini digunakan pendekatan secara deskriptif kualitatif dengan pandangan wacana kritis model Norman Fairclough (1995). Melalui perspektif analisis wacana kritis, bagaimana pembawa acara (Najwa Sihab) mengkontruksi monolog "Menanti Terawan" dicoba untuk ditelisik dan dibedah lebih lanjut. Metode pengumpulan data menggunakan metode-simak. Menurut Mahsun (2014), metode pengumpulan data dapat dibagi menjadi dua hal, yaitu metode simak dan juga metode cakap. Dalam penelitian ini menerapkan metode simak kemudian diikuti teknik simak bebas-libat-cakap, dan teknik catat. Objek dalam penelitian ini adalah monolog Najwa Sihab dalam talkshow Mata Najwa edis "Menanti Terawan". Data adalah berupa tuturan dalam talk show dan sumber data adalah youtube berupa tuturan Najwa Sihab yang ditranskripsikan secara ortografis yang terdapat pada laman https://www.youtube.com/watch?v=QQ9oYqowqO4 yang dipublikasikan pada tanggal 28 September 2020.

Teknik analisis data dilakukan dengan mengacu pada dimensi analisis wacana Fairclough. Fairclough (1989; 1992; 1995), mengemukakan tiga dimensi atau tahapan dalam analisis teks yaitu deskripsi, interpretasi dan eksplanasi yang akan digunakan sebagai teknik dalam analisis data. Dimensi pertama yaitu deskripsi yang merupakan tahap yang berkaitan dengan sifat formal wacana Fitur-fitur formal kebahasaan (kosakata dan gramatikal) di analisis dan dielaborasi dalam tahap deskripsi. Dimensi kedua yaitu interpretasi sebagi dimensi yang terkait dengan hubungan antara wacana dengan interaksi. Pada dimensi interpretasi, analisis berfokus pada faktor situasional yang melatarbelakangi lahirnya sebuah teks. Dimensi yang terakhir adalah eksplanasi sebagai dimensi yang terkait dengan hubungan antara interaksi dengan konteks sosial. Pada tahap eksplanasi, analisis dilakukan pada keterkaitan antara wacana dengan konteks sosial-kultural.

Pada bagian ini akan diuraikan analisis melalui kerangka analisis wacana kritis yang dikembangkan oleh Fairclough dalam Eriyanto (2015). Dalam pandangan Fairclough teks wacana lebih difokuskan pada penggunaan bahasa sebagai suatu praktik sosial. Oleh sebab itu, wacana dipandang sebagai bentuk dari tindakan, serta mengimplikasikan adanya hubungan timbal baik dengan struktur sosial. Berdasarkan paradigma tersebut, kerangka analisis wacana kritis menurut kaca mata Fairclough dibagi menjadi tiga dimensi, yaitu: analisis teks bahasa (lisan dan tulisan), analisis praktek wacana, serta praktik analisis sosiokultural.

\section{HASIL DAN PEMBAHASAN}

Di dalam bagian ini akan mendedah analisis wacana kritis terhadap teks monolog pada acara talkshow Mata Najwa, edisi Menanti Terawan, yang disiarkan secara langsung, di salah satu stasiun TV swasta-nasional, yang dapat diakses seluruh masyarakat Indonesia. Adapun tahapan analisis menurut 
Fairclough meliputi: (1) Analisis dimensi teks (deskripsi linguistik dari segi bahasa), dan (2) Analisis dimensi sosiokultural (eksplanasi hubungan antara teks dengan proses sosio-kultural).

\section{Analisis Dimensi Teks}

Dalam analisis wacana, peneliti perlu memulai dengan pengenalan teks. Oleh karena itu deskripsi merupakan tahap awal AWK yang mengeksplorasi perangkat tekstual teks. Badara (2012: 55) memaparkan bahwa kata, kalimat dan proposisi merupakan pilihan linguistik yang dapat mencerminkan ideologi tertentu.

Pada tahap awal analisis, Kristina (2020: 62) memberikan acuan tiga aspek yang dapat diuraikan pada analisis deskripsi teks, yaitu: struktur tekstual, kosakata, tata gramatikal atau tata bahasa.

\section{Struktur Teks Monolog}

Analisis struktur teks monolog ini berkaitan dengan penggunaan aspek kebahasaan sebagai sarana retorika yang digunakan oleh penutur dalam proses komunikasi. Penutur dalam hal ini adalah Najwa Shihab yang berlaku sebagai pembawa acara sekaligus pewawancara acara talkshow Mata Najwa tersebut. Jika dilihat dari strukturnya, teks monolog tersebut menggunakan pola retorika-terstruktur, diawali dengan pengenalan, inti pembicaraan dan penutup (Sumarlam, 2013: 2015). Selain itu teks tersebut juga memberikan informasi tentang maksud dan tujuan teks tersebut diproduksi. Pola yang terstruktur dari teks monolog tersebut terdiri atas judul/edisi, orientasi, inti pembicaraan dan penutup.

Teks monolog yang disampaikan secara lisan oleh pembawa acara Najwa Shihab, juga memiliki judul seperti halnya pada wacana tulis. Judul dapat merepresentasikan topik yang akan dibahas atau peristiwa menarik apa yang terjadi. Dalam talkshow tersebut istilah judul disepadankan dengan kata 'edisi', sehingga edisi disini dapat mewakili inti permasalahan atau kejadian penting tentang apa yang diulas atau dibahas dalam acara itu (Sholikhati, 2017). Adapun judul atau edisi yang diangkat pada teks monolog talkshow Mata Najwa ini adalah "Menanti Terawan". Jika dilihat dari struktur gramatikanya, judul itu hanya terdiri atas satu frasa dan tidak ada atribut lain yang disematkan, yang mungkin bisa memberikan petunjuk tentang apakah atau siapakah Terawan itu. Apakah menunjuk pada suatu peristiwa atau identitas persona. Hal ini dapat dipahami, karena bagi masyarakat Indonesia, jika itu dikaitkan dengan nama orang, pada umumnya cukup jarang orang yang memiliki nama tersebut. Bagi khalayak yang telah mengetahui informasi siapakah Terawan itu, tentu dapat memprediksi apa dan permasalahan apa yang terjadi pada sosok Menteri Kesehatan itu, sehingga layak untuk diangkat dan disiarkan ke ranah publik. Oleh karena itu, pemilihan judul atau edisi dengan kalimat demikian, dipandang representatif dalam memancing antusias dan perhatian masyarakat untuk ikut menyaksikan acara tersebut. Hal ini tentu sesuai dengan sifat karakteristik suatu peristiwa atau kejadian yang layak untuk diangkat ke ranah publik melalui media, yaitu menyajikan informasi yang penting, menarik, dan juga fenomenal. Semakin berita itu kontroversial maka semakin layak atau menarik untuk diungkap.

Unit kedua pada struktur teks tersebut adalah orientasi atau pengenalan. Sebelum masuk pada inti pembicaraan, seorang pembawa acara pada acara talkshow akan menyampakan orientasi atau pengenalan awal tentang inti peristiwa atau topik apa yang akan dibahas pada acara tersebut. Dalam hal ini, Najwa Shihab selaku pembawa acara menyampaikan tentang inti permasalahan yang diangkat yaitu mengenai ketidakhadiran narasumber selaku Menteri Kesehatan, yang diharapkan dapat mendedahkan kebijakan-kebijakannya terkait dengan penanganan pandemi Covid-19. Sayangnya, sudah beberapa kali menteri kesehatan Terawan Agus Putranto diundang dalam acara tersebut, namun tidak kunjung hadir, dan acara dengan topik itu tetap berlangsung dengan tuturan monolog. 
Unit ketiga adalah inti pembicaraan. Unit ini menjadi bagian penting dari sebuah teks berita, sebab mengurai secara utuh dan mendalam tentang permasalahan yang dibahas. Pada bagian ini dapat diuraikan mengenai partisipan peristiwa, tempat dan waktu terjadinya peristiwa.

Unit keempat adalah penutup. Dalam struktur wacana, penutup berfungsi untuk mengakhiri pembahasan atau penyampaian informasi. Pada acara-acara talkshow yang sering ditayangkan di berbagai stasiun TV, sebelum mengakhiri acara, pembawa acara akan menutup acara tersebut dengan berbagai style berbahasa sesuai dengan karakteristik acara itu, seperti formal, informal maupun semiformal. Ada yang berbentuk tuturan quote 'pesan bijak', penegasan, imbauan, saran dan masukan yang diwujudkan dalam pernyataan deklaratif, interogatif, maupun imperatif. Pada teks monolog ini, tuturan yang diungkapkan sebagai penutup acara adalah bentuk tuturan imperatif, yaitu "Menteri kesehatan Terawan Agus Putranto, waktu dan tempat dipersilakan!". Tuturan tersebut memiliki tujuan yang bermaksud menyatakan panggilan bahwa kedatangannya untuk memberikan klarifikasi dan keterangan, berkaitan dengan tugas yang menjadi tanggung jawabnya masih ditunggu khalayak, yaitu tentang pandemi covid 19.

\section{Struktur Kosakata Monolog}

Pilihan kosakata menjadi hal penting bagi pembicara untuk menyampaikan pesan komunikasi agar dapat dimaknai secara representatif oleh penyimak/pemirsa TV. Lebih lanjut Badara (2012: 54; Eriyanto, 2015) menyatakan suatu peristiwa yang sama jika dibahasakan dengan bahasa yang berbeda, maka akan menghasilkan realitas yang berbeda pula pada khalayak. Dengan demikian semua pilihan kata tersebut dapat menimbulkan asosiasi tertentu pada realitas yang diacu, serta reaksi yang berbeda pada khalayak. Kristina (2020: 62-64) dan Sosiowati (2013) menguraikan beberapa hal terkait dengan penjabaran struktur kosakata, yaitu: (a) nilai eksperiensial yang terkandung dalam kosakata seperti katakata yang memuat ideologi tertentu, (b) Kata dengan struktur repetisi (perulangan), sinonimi, antonimi, hiponim, (c) kata yang memuat nilai ekspresif eufemisme, superlatif, emotif, bernada formal, informal. (4) Metafora yang digunakan.

Kata Yang Mengandung Ideologi Tertentu

'Pastilah di atas tanah beradu banyak kepentingan, Namun, Pak Terawan Pak Terawan semestinya orang paling gencar memperjuangkan kepentingan kesehatan'. (Data 5)

'Adalah Pak Terawan yang punya wewenang akses anggaran dan pemberi arahan'. (Data 4) 'Sejak awal pandemi Anda terkesan menganggap virus ini bukan ancaman besar'. (Data 16)

'Apakah Anda kini mengakui bahwa kita kecolongan dalam langkah penanganan di awal yang seharusnya bisa lebih tanggap?'. (Data 17)

'Kenapa berbagai peraturan dan birokrasi masih berbelit di Kementerian Kesehatan?'. (Data 29)

'Bukankah Menkes seharusnya menjadi pelindung dan pembela utama nakes?'. (Data 32)

'Kenapa tidak terbuka dan transparan lalu menutup kantor, Pak?' (Data 38)

Kata Dengan Struktur Repetisi Dan Pemakaian Kata Ganti

'Kenapa tes kita belum juga mencapai target?' (Data 27)

'Kenapa resapan anggaran Kementerian masih rendah?' (Data 28)

'Kenapa berbagai peraturan dan birokrasi masih berbelit di Kementerian Kesehatan?' (Data 29)

'Kenapa perlindungan tenaga kesehatan kita belum maksimal?' (Data 30)

'Pak Terawan, ada banyak menteri kesehatan yang mundur karena penanganan Covid 19'. (Data 39) 
'Misalnya Menteri kesehatan New Zealand, Ceko, Polandia, Brazil, Chile, Pakistan, Israel Public Health Director-nya mundur, Canada Public Health Agency Presiden-nya mundur'. (Data 40) 'Pertanyaan saya, Pak, apakah penanganan kita lebih baik dari negara-negara yang Menkes-nya mundur itu?'. (Data 41)

Kata Yang Mengandung Metafora

'Pastilah di atas tanah beradu banyak kepentingan namun Pak Terawan semestinya orang paling gencar memperjuangkan kepentingan kesehatan'. (Data 5)

'Namun selama jabatan Menteri Kesehatan masih di tangan'. (Data 8)

Data lingual (a) dapat dilihat penggunaan kata-kata yang mendukung realisasi ideologi pembicara/pemroduksi teks. Kata-kata seperti 'memperjuangkan, ancaman, penanganan, birokrasi, berbelit, memiliki kolokasi yang secara eksplisit mengarah pada adanya ketidakjelasan, ketimpangan, tuntutan yang mendesak dan permasalahan yang tidak kunjung terselesaikan. Sedangkan kata 'pelindung, pembela, dan transparan' memiliki kolokasi yang mengarah pada orang atau institusi yang memiliki power/kekuatan_dalam hal ini dapat berperan sebagai pemimpin/pengambil kebijakan dan keputusan_, yang dapat berpengaruh pada banyak pihak. Sehingga kemunculan kata-kata tersebut menyiratkan adanya ketimpangan atau ketidakjelasan permasalahan yang menyangkut khalayak, yang berada di bawah kekuasaan pihak tertentu.

Selain pilihan kata tersebut, bentuk repetisi yang muncul seperti pada data (b) juga dapat mendukung ideologi pemroduksi teks. Bentuk repetisi 'kenapa' yang diulang sebanyak tiga kali di setiap awal kalimat, menyiratkan sebuah penegasan terhadap tuntutan adanya kejelasan. Hal itu dilakukan sebagai sesuatu yang mewakili keinginan khalayak mengenai kejelasan masalah yang ada di ranah kerjanya, yang selama ini tidak kunjung diberitahukan/dikemukakan.

Pemakaian kata ganti 'kita' yang dipilih pembicara, bertujuan untuk mendekatkan jarak sosial antara penutur dengan partisipan. Kata ganti yang termasuk pronomina persona jamak bentuk bebas tersebut, dapat mencakup acuan: pemroduksi teks, partisipan yang dalam hal ini adalah menteri kesehatan, serta khalayak. Penggunaan kata tersebut dimaksudkan agar partisipan menyadari bahwa dirinya merupakan bagian dari komunitas publik yang sedang mengalami permasalahan yang sama.

Untuk dapat mengkonkretkan gagasan pembicara agar apa yang diutarakan dapat dipahami partisipan maupun khalayak dengan baik, maka penggunaan metafora dapat mendukung gambaran bagaimana realitas ditampilkan, seperti dalam contoh data (c1) dan (c2). Pada ungkapan tersebut frasa 'di atas tanah beradu' sebagai komponen wahana yang mengacu pada setting tempat dan kondisi yaitu di Indonesia, sedangkan frasa 'banyak kepentingan' merupakan komponen tenor yang mewakili pihakpihak dari berbagai bidang yang terdampak. Di dalam perbandingan antara tenor dan wahana, pemroduksi teks hendak menampilkan gambaran bagaimana pihak-pihak dari berbagai bidang yang terdampak tersebut saling bersitegang, desak mendesak dalam memperjuangkan kepentingan masingmasing. Melalui analogi tersebut, pihak partisipan dalam hal ini adalah menteri kesehatan Terawan, diharapkan dapat segera mengatasi permasalahan terkait pandemi Covid-19 yang terjadi di Indonesia dalam domain atau ranah kerjanya yang juga memiliki pengaruh signifikan terhadap ranah lain. Hal itu juga didukung dengan analogi metafora yang ditunjukkan melalui frasa dipundaknya. Hal ini dapat memberikan gambaran yang spesifik, bahwasannya selama menteri kesehatan masih dijabat oleh Terawan, apapun resikonya, tugas dan tanggung jawab terkait dengan penanganan Covid 19 yang ada di ranahnya, berada pada kewenangan dan kekusaannya sebagai pemegang kebijakan. Dengan 
demikian penggunaan analogi tersebut sebagai upaya pengkonkretan gambaran kepada khalayak, sekaligus persuasif yang bernada desakan kepada partisipan.

\section{Struktur Tata Bahasa (Gramatika) Monolog}

Struktur tata bahasa (gramatika) yang dikemukanan oleh Kristina (2020) ini, sepadan dengan kerangka yang diuraikan Eriyanto (2015), yang meliputi unsur representasi kumpulan anak kalimat, dan representasi kumpulan kalimat. Dalam kerangka Kristina (2020), struktur tata bahasa (gramatika) dapat meliputi : tipe proses dan tindakan partisipan, jenis kalimat aktif/pasif, positif/negatif, nominalisasi, Modalitas yang digunakan, Tipe hubungan antarkalimat.

Tipe Proses Dan Tindakan Partisipan

Dalam bentuk proses ini, seseorang, kelompok, kegiatan ditampilkan sebagai tindakan, peristiwa atau keadaan. Penggunaan klausa aktif dengan verba transitif kala kini dapat mengungkapkan makna ideasional tentang berlangsungnya suatu proses. Sedangkan pada tindakan partisipan, melihat bagaimana aktor ditampilkan sebagai pelaku atau korban dalam pemberitaan. Jika partisipan sebagai pelaku, pada umumnya ditampilkan dengan kalimat aktif. Jika partisipan sebagai korban, maka pada umumnya digunakan bentuk kalimat pasif. Adapun contoh yang terdapat dalam wacana monolog Mata najwa adalah sebagai berikut:

'Tentu tak ada sosok yang lebih tepat bicara kepada publik kepada kita memberi penjelasan'. (Data 2)

'Pastilah di atas tanah beradu banyak kepentingan namun Pak Terawan semestinya orang paling gencar memperjuangkan kepentingan kesehatan'. (Data 5)

'Anda minim sekali muncul di depan publik memberi penjelasan selama pandemi'. (Data 12)

'Sejak awal pandemi Anda terkesan menganggap virus ini bukan ancaman besar'. (Data 16)

'Atau bagaimana Anda bisa meyakinkan publik, Bahwa memang masih layak menjalankan atau menduduki posisi yang berat ini?'. (Data 44 dan 45)

'Kami tahu takkan ada yang bisa menyelesaikan persoalan pandemi ini sendirian'. (Data 48)

'Tapi kami berharap Anda setidaknya bersedia untuk memberi gambaran'. (Data 49)

Pada data 1) -7) jenis predikat yang muncul pada setiap klausa, hampir keseluruhannya berjenis verba transitif, atau kata kerja transitif sehingga membentuk kalimat aktif transitif. Melalui kata kerja tersebut dapat dilihat bahwa pemroduksi teks merepresentasikan subyek, yaitu Menteri Kesehatan Terawan sebagai pelaku yang melakukan tindakan. Sedangkan obyeknya dapat berupa khalayak, ataupun elemen yang menjadi bagian dari permasalahan yang mengemuka. Subjek diungkapkan melalui pilihan bahasa yang berbeda-beda. Ada yang secara implisit melalui ungkapan tertentu, pronomina, maupun secara eksplisit dengan langsung menyebut nama dan gelarnya, yang keseluruhannya mengacu pada Menteri Kesehatan Terawan Agus Putranto. Pemakaian varian tersebut oleh pemroduksi teks, juga difungsikan untuk menunjukkan kualitas hubungan relasional antara pemroduksi teks dengan partisipan. Seperti pemakaian pronomina anda, kita, penyebutan nama langsung dengan sapaan Pak dan Bapak. Hal itu dapat merepresentasikan identitas pemroduksi teks yaitu sebagai bagian dari pihak yang berada di bawah kekuasan pemegang kebijakan, yaitu Terawan yang memiliki power dalam memberikan kejelesan dan transparansi atas kinerja yang ada di wilayah tanggung jawabnya.

Pada teks monolog, Terawan sebagai aktor yang menjadi fokus pemberitaan, selalu disertai dengan klausa verbal aktif transitif. Penggunaan klausa aktif dengan verba transitif kala kini dapat mengungkapkan makna ideasional tentang berlangsungnya suatu proses (Eriyanto, 2015). Realitas tersebut sesuai dengan apa yang tergambar dalam teks, bahwasannya, aktor yang menjadi fokus 
pemberitaan adalah Terawan selaku menteri kesehatan, dan berada pada suatu kondisi/proses yang sedang berlangsung, yaitu terkait dengan penanganan covid-19.

Kalimat aktif lain dengan pemroduksi teks (dalam hal ini diwakili oleh presenter Najwa Shihab) sebagai subjek, juga beberapa menunjukkan proses tindakan yang berkaitan langsung dengan partisipan Menteri Terawan, yaitu menyatakan upaya untuk dapat menghadirkan partisipan dan meminta klarifikasi atau pernyataannya terkait dengan kebijakan tentang penanganan covid 19. Pemroduksi teks diungkapkan dengan pronomina 'kami' untuk mewakili tim kreatif, dan bukan hanya presenter Mata Najwa saja. Selain itu, pemakaian pronomina tersebut sebagai bentuk identifikasi pemroduksi teks terhadap kepentingan khalayak.

Kalimat Positif Dan Negatif

Sikap positif dan negatif yang salah satunya dapat dibangun melalui kala, modus dan kata emotif, sedikit banyak dapat menunjukkan bagaimana sikap pemroduksi teks berita terhadap suatu peristiwa atau tokoh. Adapun beberapa pemakaian aspek tersebut dapat dilihat pada contoh:

'Tentu tak ada sosok yang lebih tepat bicara kepada publik kepada kita memberi penjelasan'. (Data 2)

'Tanggung jawab terbesar tak bisa lepas dari pundaknya'. (Data 9)

'Rasanya menteri kesehatan yang paling low-profile di seluruh dunia selama wabah ini, hanya Menteri Kesehatan Republik Indonesia'. (Data 13 dan 14)

'Anda minim sekali muncul di depan publik memberi penjelasan selama pandemi'. (Data 12)

'Atau kehadiran Menteri Kesehatan di muka publik memang Anda rasa tidak terlalu penting?'. (Data 15)

'Sejak awal pandemi Anda terkesan menganggap virus ini bukan ancaman besar'. (Data

16)

'Apakah Anda kini mengakui bahwa kita kecolongan dalam langkah penanganan di awal yang seharusnya bisa lebih tanggap?'. (Data 17)

'Pak Terawan, sampai sekarang kondisi pandemi belum juga terkendali'. (Data 20)

'Kenapa tes kita belum juga mencapai target?'. (Data 27)

Pada data tersebut, pemakaian modus, kala dan kata emotif dapat menunjukkan bagaimana pemroduksi teks memandang positif atau negatif aktor. Pemakaian bentuk negasi 'tak' di dalam konstruksi gramatikal dapat memberikan penegasan, sekaligus menunjukkan bagaimana perspektif dari sudut pandang pemroduksi teks terhadap partisipan. Selain itu juga dapat menunjukkan bagaimana strategi pemroduksi teks di dalam memberikan daya persuasif, khususnya desakan kepada partisipan.

Pemakaian kala 'belum' pada beberapa konteks kalimat itu dapat memproyeksikan pandangan pemroduksi teks terhadap aktor/partisipan, yaitu adanya proses yang masing berlangsung/belum selesai dan belum ada kejelasan/transparansi, sehingga dalam konteks tersebut mengungkapkan adanya ketidakpastian, khususnya dalam hal ini adalah penanganan kasus Covid 19.

Pemakaian negasi 'tidak' dalam konteks kalimat itu juga menunjukkan bahwa pemroduksi teks memberikan penilaian negatif terhadap aktor. Modus 'bisa' yang pada umumnya berarti kemampuan, dalam konteks kalimat itu lebih digunakan untuk memojokkan. Sedangkan kata emotif 'paling', menjadi ciri penanda kalimat positif, namun demikian, jika dicermati dalam konteks tuturan tersebut, hal itu justru sebagai suatu ironi yang bernada sebaliknya yang ditujukan terhadap Terawan.

Adapun beberapa tuturan yang menggunakan jenis kalimat direktif, interogatif dan imperatif juga merupakan strategi bagi pemroduksi teks dalam menunjukkan ideologinya, serta penilaian secara tidak langsung terhadap partisipan. Kalimat-kalimat direktif yang digunakan, banyak menggunakan bentuk modalitas, kala dan emotif yang lebih cenderung mendesak dan memojokkan. Hal ini juga didukung 
dengan kalimat-kalimat interogatif yang dituturkan pemroduksi teks. Dalam struktur teks monolog, penggunaan kalimat-kalimat interogatif yang juga memasukkan unsur modus dan kala, dalam beberapa kali tuturan, dapat menunjukkan keragu-raguan pihak pemroduksi teks terhadap partisipan. Dalam hal ini keragu-raguan itu meliputi: ide, tindakan, dan hasil dari apa yang dilakukan oleh partisipan di waktu lampau, kini dan prediksi di kemudian hari. Begitu juga dengan kalimat imperatif pada akhir atau penutup acara, dimana pihak Najwa Shihab mempersilahkan Pak Menteri untuk menempati kursi yang masih kosong, yang tersedia untuknya. Hal itu lebih bernada ironi, karena jelas-jelas Menteri Kesehatan atau partisipan yang dimaksud sedang tidak berada di tempat tersebut. Namun demikian, tuturan itu sebagai ironisme, karena permohonan dari pihak pemroduksi teks tidak dilakukan.

Dengan demikian dapat dikatakan bahwa tuturan yang ditandai dengan beberapa ciri linguistik seperti yang terdapat pada data dapat merepresentasikan ideologi negatif pemroduksi teks terhadap aktor, yaitu Menteri Kesehatan Terawan Agus Putranto.

\section{Dimensi Sosiokultural (Eksplanasi)}

Dalam dimensi ekplanasi, penafsiran pada tahap deskripsi dan tahap interpretasi dijelaskan dengan melihat hubungan diantara praktik wacana dan konteks sosio-kultural. Pada dimensi ini, kondisi sosio-kultural dijelaskan dengan membagi dalam tiga bagian (Sumarlam, 2016), yakni (1) Situasional, yang merupakan situasi ketika sebuah teks diproduksi. (2) Institusional, yang melihat pengaruh dari institusi organisasi terhadap teks yang diproduksi. (3) Sosial, ditafsirkan dengan mengamati hal-hal makro, dalam masyarakat terkait dengan kepentingan-kepentingan politik, sosial, serta budaya di Indonesia.

\section{Proses Perubahan Situasi}

Proses perubahan situasi yang mengawali kemunculan monolog bangku kosong sebagai representasi Menteri Kesehatan adalah berawal dari ketidakhadiran Menteri Kesehatan untuk memenuhi undangan tim Mata Najwa. Situasi dimulai dari adanya beberapa pernyataan kontroverisal yang dirangkum dalam berita yang dilansir dalam laman kompas.com tanggal 29 September 2020 menyebutkan bahwa Menteri Kesehatan meminta masyarakat bersyukur bahwa korona tidak terdeteksi di Indonesia yang disampaikan pada tanggal 11 Februari 2020. Pada tanggal 15 Februari 2020, Menteri Kesehatan kembali menyampaikan pernyataan kontroversial saat menanggapi melonjaknya harga masker dengan menyalahkan orang-orang yang membeli masker. Pernyataan yang kontroversial kembali juga dinyatakan oleh Menteri Kesehatan dengan menyatakan bahwa kekuatan doa menjadi penyebab korona tidak masuk ke Indonesia yang disampaikan pada tanggal 17 Februari 2020. Kemudian, Menteri Kesehatan Terawan dalam keterangan yang disampaikan di kantor Kementerian Kesehatan pada tanggal 02 Maret 2020 mengatakan bahwa publik tidak perlu khawatir karena penyakit flu biasa justru mempunyai angka kematian lebih tinggi daripada virus korona..

Setelah menyampaikan beberapa pernyataan kontroversial tersebut, menteri Kesehatan jarang muncul di publik dalam waktu yang lama dan digantikan oleh jubir satgas penanganan covid-19 sebagai perantara komunikasi pemerintah terkait dengan persoalan pandemi. Padahal, dalam situasi pandemi justru sosok yang dicari dan ditunggu kehadirannya adalah Menteri Kesehatan yang diharapkan memberikan informasi dan kebijakan terkait penanganan pandemi. Dalam proses pencarian informasi tersebut, program Mata Najwa berkali-kali mengundang Menteri Kesehatan akan tetapi tidak direspon dengan alasan sibuk dan bahkan diabaikan seperti dalam berita yang dilansir dalam berita nasional.kompas.com. Akhirnya, mewawancarai kursi kosong dipilih tim Najwa Shihab sebagai langkah terakhir untuk meneruskan berbagai permintaan petanyaan dari masyarakat terkait pandemi. Hal ini 
menunjukkan bahwa tidak ada pilihan lain bagi tim Mata Najwa untuk bisa menghadirkan Menteri Kesehatan dalam acaranya.

\section{Proses Perubahan Institusi}

Setelah tayang di Media televisi dan media sosial, talkshow monolog bangku kosong Terawan mendapatkan tanggapan pro dan kontra di tengah masyarakat. Berbagai pemberitaan di institusi media (cetak maupun elektronik) ikut menyuguhkan berita faktual terkait dengan kontroversi opini publik dengan penayangan tersebut. Dalam beberapa media ramai di beritakan terkait pihak yang kontra yaitu yang melaporkan Najwa Shihab ke polisi karena dianggap sudah melakukan cyber bullying. Di lain pihak, media juga menyuguhkan informasi komentar para pengamat dan politisi yang pro dengan memberi dukungan pada tayangan tersebut. Sebagai contoh, berita terkait opini anggota DPR yaitu Fadli Zon yang turut serta menyampaikan pembelaannya pada Najwa Shihab. Bahkan, muncul petisi yang berada di laman change.org yang meminta pencopotan Menteri Kesehatan yang sudah diisi oleh sejumlah lembawa swadaya masyarakat dan pribadi. Dewan Berbagai media memberitakan dan menggiring opini publik tentang kegagalan Menteri Kesehatan dalam penanganan pandemi. Akhirnya, pada tanggal 22 Desember 2020, Presiden Joko Widodo mengumumkan susunan baru Kabinet Indonesia Maju. Salah satu nama yang diresuffle adalah Menteri Kesehatan Terawan Agus Putranto yang digantikan oleh wakil Menteri BUMN yang seorang bankir, yaitu Budi Gunadi Sadikin. Dalam pemberitaan di beberapa media, resuffle menteri kesehatan tersebut erat dikaitkan dengan ketidakberhasilan Menteri Kesehatan dalam menangani pandemi di Indonesia.

\section{Proses Perubahan Sosial}

Acara talkshow monolog bangku kosong Terawan yang semula ditayangkan di media televisi diunggah kembali melalui media sosial youtube yang merupakan platform media yang banyak dikunjungi oleh berbagai kalangan. Video tersebut menjadi trending topik di media sosial dan youtube. Bahkan jumlah penonton pada channel youtube tersebut mendapatkan perhatian lebih dari 4,5 juta orang. Dengan banyaknya atensi terhadap tayangan tersebut menunjukkan bahwa banyak yang penasaran dengan pesan dan makna yang ingin disampaikan dalam cara tersebut. Berbeda dengan budaya sosial dalam media televisi di mana para penonton tidak bisa secara langsung ikut berkomentar dalam acara, media youtube mempunyai fitur komentar yang di dalamnya para penonton dengan bebas mengekspresikan berbagai opini terkait tayangan. Komentar dalam video \#MataNajwaMenantiTerawan mencapai 57 ribu lebih mengindikasikan bahwa masyarakat antusias dalam memberikan pendapat tentang penayangan video tersebut. Hal ini menunjukkan bahwa terdapat perubahan sosial dimana masyarakat yang sebelumnya tidak bisa ikut menyampaikan aspirasinya ke dalam suatu tayangan yang bersifat publik, dengan adanya media sosial masyarakat dapat berkontribusi dalam menyampaikan opini, pertanyaan, dan komentar terkait dengan acara bangku kosong Terawan.

\section{SIMPULAN}

Berdasarkan pada analisis wacana kritis terhadap tuturan monolog dalam talk show Mata Najwa edisi "Menanti terawan", maka dapat disimpulkan bahwa tuturan yang menggunakan jenis kalimat direktif, interogatif dan imperatif juga merupakan strategi bagi pemroduksi teks dalam menunjukkan ideologinya, serta penilaian secara tidak langsung terhadap partisipan. Dimensi Teks, pertama, teks monolog tersebut menggunakan teknik yang berpola retorika terstruktur, diawali dengan pengenalan (orientasi), inti pembicaraan dan penutup. Kedua, kosakata monolog kolokasi yang secara eksplisit, kolokasi yang mengarah, repetisi, pronomina persona, metafora. Ketiga, tata bahasa (Gramatika) monolog. Dalam 
dimensi sosial-kultural adanya perubahan situasi, perubahan instritusi dan peubahan sosial. Dimensi interpretasi bertipe proses dan tindakan partisipan, jenis kalimat aktif/pasif, positif/negatif, nominalisasi, modalitas yang digunakan.

\section{DAFTAR RUJUKAN}

Badara, Aris. (2012). Analisis Wacana Teori, Metode, dan Penerapanya padaWacana Media. Jakarta: Kencana Prenada Media Group.

Eriyanto. (2001). Analisis Wacana: Pengantar Analisis Teks Media. Yogyakarta: LkiS

Fairclough, Norman. (1989). Language and Power. London and New York: Longman.

Fairclough, Norman. 1992. Discourse and Text: Linguistic and Intertextual Analysis Within Discourse Analysis. Sage Journal Vol. 3(2). 193-217. London, New Bury Park, and Delhi.

Fairclough, Norman. 1995. Critical Discourse Analysis: The Critical Study of Language. London and New York: Longman Group Limited.

Kritina, Diah. (2020). Analisis Wacana Kritis: Pengantar Praktis. Yogyakarta: Pustaka Pelajar.

Mahsun, M. S. (2014). Metode Penelitian Bahasa Metode Penelitian Bahasa: Tahapan Strategi Metode dan Tekniknya. Jakarta: Raja Grafindo Persada.

Mardikantoro, Hari Bakti. (2014). Analisis Wacana Kritis pada Tajuk (Anti) Korupsi di Surat Kabar Berbahasa Indonesia. Jurnal Litera Vol. 13, Nomor 2. Yogyakarta: FBS UNY.

Payuyasa, I. N. (2017). Analisis wacana kritis model van dijk dalam program acara mata najwa di metro tv. Segara Widya: Jurnal Hasil Penelitian Dan Pengabdian Masyarakat Institut Seni Indonesia Denpasar, 5.

Sosiowati, I Gusti Ayu Gede. (2013). "Kesantunan Bahasa Politisi dalam Talk Show di Metro TV". Disertasi. Denpasar: Universitas Udayana.

Sumarlam, S. (2016). Representasi Kekuasaan Melalui Sabda Raja Pada Teks Berita Mengenai Konflik Internal Keraton Yogyakarta (Sebuah Analisis Wacana Kritis). Prosiding prasasti, 58-70.z

Sholikhati, NI., Mardikantoro, HB. (2017). Analisis Tekstual dalam Konstruksi Wacana Berita Korupsi di Metro TV dan NET dalam Perspektif Analisis Wacana Kritis Norman Fairclough. Seloka: Jurnal Pendidikan Bahasa dan Sastra Indonesia Vol. 6 No. 1.

Syaifudin N, Zain. (2013). "Implikatur dan Kesantunan Positif Tuturan Jokowi dalam Talk Show Mata Najwa dan Implementainya Sebagai Bahan Ajar Bahasa Indonesia di SMK". Jurnal Penelitian Humaniora, Vol 14 No. $1 \mathrm{hlm}$ 55-70. Surakarta: Universitas Muhammadiyah Surakarta.

Widyawari, Zulaeha. (2016). Representasi Ideologi dalam Tuturan Santun Para Pejabat Negara pada Talk Show Mata Najwa. Seloka: Jurnal Pendidikan Bahasa dan Sastra Indonesia Vol. 5 No. 1.

Wibowo, Setiawan Edi. (2013). "Kesantunan Humor Pejabat dalam Wawancara: Kajian Pragmatik (Studi Kasus Pembelajaran di Kelas". Litera, Vol 13, No 1, April. Yogyakarta: UNY. 